\title{
Perspectives on Zygomatic Implants
}

Editors

ANASTASIYA QUIMBY

SALAM SALMAN

ATLAS OF THE ORAL AND
MAXILLOFACIAL SURGERY
CLINICS OF NORTH AMERICA

www.oralmaxsurgeryatlas.theclinics.com

Consulting Editor

RUI P. FERNANDES

September 2021 - Volume 29 - Number 2 